\title{
Improved Growth and Harvestable Yield through Optimization of Fertilizer Rates of Soil-applied Nitrogen, Phosphorus, and Potassium in Wild Blueberry (Vaccinium angustifolium Ait.)
}

\author{
Rizwan Maqbool ${ }^{1}$
}

Department of Agronomy, Faculty of Agriculture, University of Agriculture Faisalabad, Pakistan 38040; and Department of Environmental Sciences, Faculty of Agriculture, Dalhousie University, Truro, Nova Scotia, Canada B2N $5 E 3$

\author{
David Percival \\ Department of Environmental Sciences, Faculty of Agriculture, Dalhousie \\ University, Truro, Nova Scotia, Canada B2N 5E3
}

Qamar Zaman and Tess Astatkie

Department of Engineering, Faculty of Agriculture, Dalhousie University, Truro, Nova Scotia, Canada B2N 5E3

Sina Adl

Department of Soil Science, College of Agriculture and Bioresources, University of Saskatchewan, Saskatoon, Saskatchewan, Canada S7N 5 A8

Deborah Buszard

Office of the Deputy Vice-Chancellor and Principal, The University of British Columbia, Okanagan campus, British Columbia, Canada V1V 1 V7

Additional index words. response surface methodology, growth, development, berry yield, nutrition, optimization, lowbush blueberry

\begin{abstract}
The study examined the main and interactive effects of soil-applied fertilizers [nitrogen (N), phosphorus (P), and potassium (K)] from a 12-year (six production cycles) field experiment conducted at Kemptown, Nova Scotia (Canada). It also recommends the optimum rate for improved growth and harvestable yield of wild blueberry (Vaccinium angustifolium Ait.). The fertilizers were applied in a single application at the onset of shoot emergence in early spring of each sprout year at rates of $0,12,30,48$, and $60 \mathrm{~kg} \cdot \mathrm{ha}^{-1} \mathrm{~N}$ using urea (2000 only) or ammonium sulfate, $0,18,45,78$, and $90 \mathrm{~kg} \cdot \mathrm{ha}^{-1} \mathrm{P}$ using triple super phosphate, $0,12,30,48$, and $60 \mathrm{~kg} \cdot \mathrm{ha}^{-1} \mathrm{~K}$ using potassium chloride. Response surface analysis of the data indicated that $35 \mathrm{~kg} \cdot \mathrm{ha}^{-1} \mathrm{~N}, 40 \mathrm{~kg} \cdot \mathrm{ha}^{-1} \mathrm{P}$, and $30 \mathrm{~kg} \cdot \mathrm{ha}^{-1} \mathrm{~K}$ were optimum for fruit production and maintaining stem lengths $<20 \mathrm{~cm}$, and resulted in an average of $54 \%$ more floral buds, $25 \%$ more berries per stem, and $13 \%$ greater yield than previous recommend rates of $20 \mathrm{~kg} \cdot \mathrm{ha}^{-1} \mathrm{~N}, 10 \mathrm{~kg} \cdot \mathrm{ha}^{-1} \mathrm{P}$, and $15 \mathrm{~kg} \cdot \mathrm{ha}^{-1} \mathrm{~K}$. The higher fertilizers rates cost an extra $\$ 80 / \mathrm{ha}$ but increased net profits by $\$ \mathbf{4 9 0 / h a}$. Findings of this study could contribute toward better farm profitability in areas with similar growing conditions. They also suggest that modifications to existing fertilizer rates be made for Central Nova Scotia wild blueberry.
\end{abstract}

Wild blueberry ( $V$. angustifolium) is well adapted to orthic humo-ferric podzols. These soils are typically sandy, acidic ( $\mathrm{pH} 3.9-5.5)$, highly leached, poorly buffered with welldeveloped organic horizons. Podzols are not naturally fertile. However, these soils can

Received for publication 16 Dec. 2013. Accepted for publication 18 July 2016.

${ }^{1}$ Corresponding author. E-mail: maqbool.rizwan@ dal.ca.

1092 soil and accounts for $75 \%$ to $85 \%$ of the total plant dry weight (Jeliazkova and Percival, 2003). The rhizomes serve as a reservoir for nitrogenous compounds as well as carbohydrates and some inorganic constituents particularly N, P, and magnesium (Townsend et al., 1968). The numerous fine, hair roots are heavily colonized by indigenous ericoid mycorrhizal fungi that assist with nutrient uptake notably $\mathrm{N}$ and $\mathrm{P}$ and the acquisition of nutrients from organic sources that are normally unavailable to host plant roots (Read et al., 2004). The boreal forest species have been known to uptake organic $\mathrm{N}$ forms irrespective of different type of roots (Näsholm et al., 1998; Persson and Näsholm, 2001), and indirect evidence suggests that wild blueberry utilizes organic N (Maqbool, 2014).

Wild blueberry nutrient management varies considerably compared with typical tilled crop systems. Berries are removed from the fields every 2 years (cropping cycle) while extensive plant debris deposition to fields occurs in every production cycle in the form of leaf drop in fall and every 2 years in the form of pruning when the plants are mowed after harvest. As a result, wild blueberry soils contain as much as $10 \%$ organic matter (Kinsman, 1993). The wild blueberry fields have a fungal dominated soil system that promotes a slow cycling of nutrients and a low availability of nutrients. Nutrients tied in the organic matter are slowly available to plants through mineralization and nitrification is slow under low $\mathrm{pH}$ conditions typical of wild blueberry soils (Kinsman, 1993). Therefore, ammonium is the dominant form of $\mathrm{N}$ present in wild blueberry soils and $\mathrm{P}$ may not be readily available to plants due to the soils high acidity. Since irrigation is rarely used, blueberry plants are occasionally (1-3 years in a decade) exposed to drought which may significantly reduce berry yield by affecting floral bud development, berry weight, mineralization rates, and fertilizer response. The dynamic nature of interactions among plant and soil factors results in tremendous amount of uncertainty in wild blueberry nutrient management (Percival and Sanderson, 2004).

Plant growth and development (shoot number and fruit development) can almost double when ammonium is used instead of nitrate N (Cain, 1952; Townsend, 1969). Studies have also reported toxic effects of nitrate $\mathrm{N}$ on blueberries (Cain, 1952).

Fertilization generally promotes floral nodes, fruit set, and berry yield (Percival and Sanderson, 2004). For example, application of $\mathrm{N}\left(43 \mathrm{~kg} \cdot \mathrm{ha}^{-1}\right)$ in the form of urea produced $22 \%$ more flower buds per stem and $25 \%$ more yield over unfertilized plants (Smagula and Hepler, 1978). However, an excess of N applied in the sprout year may reduce yield by promoting vegetative growth, increasing weed growth, causing micronutrient imbalances, increasing susceptibility to winter injury (excessively tall stems), or stimulating an overproduction of flower buds relative to the nutrient budget in the crop year (Benoit et al., 1984; Penney and McRae, 2000; Smagula, 1999; Yarborough et al., 1986). Yet, in Maine, high $\mathrm{N}$ application rates $\left(20-98 \mathrm{~kg} \cdot \mathrm{ha}^{-1}\right)$ increased izer ations. In Nova Scotia (Car commercial growers apply fertilizers in of diammonium phosphate or am at rate of $20 \mathrm{~kg} \cdot \mathrm{ha}^{-1} \mathrm{~N}, 10 \mathrm{~kg} \cdot \mathrm{ha}^{-1} \mathrm{P}$, and $15 \mathrm{~kg} \cdot \mathrm{ha}^{-1} \mathrm{~K}$ at the onset of shoot emergenc from rhizomes in the sprout year of the production cycle (personal observations).

The extensive root and rhizome system in wild blueberry occurs within the top $10 \mathrm{~cm}$ of 
stem length, flower buds, number of berries, and yield (Smagula and Dunham, 1995; Smagula and Hepler, 1978; unpublished data). The impact of $\mathrm{N}$ applications on berry yield has been inconsistent, with studies reporting yield gains (Ismail et al., 1981; Percival et al., 2003; Smagula and Hepler, 1978), yield reductions (Penney and McRae, 2000; Smagula and Ismail 1981), or no effect (Benoit et al., 1984; Blatt, 1993).

Variable responses in soil-applied $\mathrm{P}$ and $\mathrm{K}$ have also been reported. P can either significantly increase berry yield (Smagula and Dunham, 1995) or have no effect on yield potential as expressed in buds per stem) (Eaton et al., 1997). K was found to increase yield and berry size up to $40 \mathrm{~kg} \cdot \mathrm{ha}^{-1} \mathrm{~K}$ with no additional response occurring at higher rates (Eck, 1983). Percival and Sanderson (2004) found significant effects of soil-applied $\mathrm{N}$ and $\mathrm{K}$ for fruit set on Kemptown site, and soil-applied K on Mount Vernon site despite large levels of inherent phenotypic variability. They also reported that the harvestable yield of the unfertilized treatments was as much as $36 \%$ lower than the other soil-applied $\mathrm{N}-\mathrm{P}-\mathrm{K}$ treatments at Mount Vernon. One limitation from the

Table 1. Experimental range and levels of the independent variables.

\begin{tabular}{lccccc}
\hline & \multicolumn{5}{c}{ Range and levels } \\
\cline { 2 - 6 } Original factors & -1.68 & -1 & 0 & 1 & 1.68 \\
\hline $\mathrm{N}\left(\mathrm{kg} \cdot \mathrm{ha}^{-1}\right): \mathrm{X}_{1}$ & 0 & 12 & 30 & 48 & 60 \\
$\mathrm{P}\left(\mathrm{kg} \cdot \mathrm{ha}^{-1}\right): \mathrm{X}_{2}$ & 0 & 18 & 45 & 72 & 90 \\
$\mathrm{~K}\left(\mathrm{~kg} \cdot \mathrm{ha}^{-1}\right): \mathrm{X}_{3}$ & 0 & 12 & 30 & 48 & 60 \\
\hline
\end{tabular}

previous studies was that fertilizer treatments were not varied across the entire range and mostly one or two nutrients were studied thus ignoring the full spectrum of interactions when applying nutrients from deficiency to over saturation levels.

The first objective of this research was to determine the main and interactive effects of soil-applied N-P-K fertilizers on wild blueberry growth, development, and berry yield while the second objective was to recommend fertilizer rates that optimize these same factors. We chose to use response surface methodology and canonical analysis as aids in modeling and examining the relationships between fertilizer rates and plant responses. The central composite design (CCD), the most efficient design for response surface analysis, considers several factors simultaneously, and allows the determination of the interactions among factors using a smaller number of experiments (Myers et al., 2009). This methodology has been used by others to describe the effects of fertilization on plant growth. For example, Lippke et al. (2006) evaluated soil-applied fertilizers ( $\mathrm{N}$ and $\mathrm{P}$ ) on annual ryegrass (Lolium multiflorum Lam.). The fitted response surface models provided optimum $\mathrm{N}$ and $\mathrm{P}$ levels for maximum dry matter yield. Sanchez (2000) used response surface methods with quadratic models to examine the effect of water and $\mathrm{N}$ on lettuce (Lactuca sativa L.). In this study, it was used to determine the optimum levels of soilapplied $\mathrm{N}-\mathrm{P}-\mathrm{K}$ fertilizers that could maximize yield and potential yield factors.

Table 2. Analysis of variance $P$ values of the central composite design for stem length, vegetative nodes, floral nodes, berries per stem, and berry yield.

\begin{tabular}{lccccrr}
\hline $\begin{array}{l}\text { Source of } \\
\text { variation }\end{array}$ & $\begin{array}{c}\text { Degrees of } \\
\text { freedom }\end{array}$ & $\begin{array}{c}\text { Stem } \\
\text { length }\end{array}$ & $\begin{array}{c}\text { Vegetative } \\
\text { nodes }\end{array}$ & $\begin{array}{c}\text { Floral } \\
\text { nodes }\end{array}$ & $\begin{array}{r}\text { Berries } \\
\text { per stem }\end{array}$ & $\begin{array}{r}\text { Berry } \\
\text { yield }\end{array}$ \\
\hline Blocks (years ${ }^{2}$ ) & 5 & $<0.01$ & $<0.01$ & $<0.01$ & $<0.01$ & $<0.01$ \\
Regression & 9 & $<0.01$ & 0.05 & $<0.01$ & 0.02 & $<0.01$ \\
Lack of fit & 75 & 0.88 & 0.89 & 0.56 & 0.99 & 0.99 \\
Adjusted $R^{2}$ & & 0.78 & 0.88 & 0.89 & 0.94 & 0.89 \\
Significant effects & & $\mathrm{N}, \mathrm{P}, \mathrm{PK}$ & $\mathrm{N}, \mathrm{PP}$ & $\mathrm{N}, \mathrm{NN}, \mathrm{PP}, \mathrm{KK}$ & $\mathrm{N}, \mathrm{PK}$ & $\mathrm{N}, \mathrm{NK}$ \\
\hline
\end{tabular}

${ }^{2}$ Years when wild blueberry crop was harvested in alternate years following 2-year production cycle (2001, 2003, 2005, 2007, 2009, and 2011). Year was used as blocking factor to account for year-to-year variability.

\section{Materials and Methods}

Experimental design, field experiment, and data collection. A three factor $(\mathrm{N}-\mathrm{P}-\mathrm{K})$ CCD (Myers et al., 2009) was used to study the response surfaces. The treatment combinations consisted of five levels of fertilizer $\mathrm{N}$ $\left(0,12,30,48\right.$, and $\left.60 \mathrm{~kg} \cdot \mathrm{ha}^{-1}\right), \mathrm{P}(0,18,45$, 78 , and $\left.90 \mathrm{~kg} \cdot \mathrm{ha}^{-1}\right)$, and $\mathrm{K}(0,12,30,48$, and $60 \mathrm{~kg} \cdot \mathrm{ha}^{-1}$ ). The range and levels (original and coded) for the CCD are provided in Table 1. Within each year, all design settings were replicated four times. The plot size was $6 \mathrm{~m} \times 8 \mathrm{~m}$ and each replication was randomized separately.

The field experiment was established in the Spring 2000 on a commercial field (N

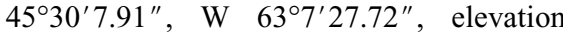
$\approx 223 \mathrm{~m}$ ) in Kemptown, Nova Scotia, Canada. The soil was included in the Cobequid soils association, classified either as gleyed sombric ferro-humic or gleyed humo-ferric podzol (Agriculture Canada, 1991). The soil $\mathrm{pH}$ was 4.3 (0 to $15 \mathrm{~cm}$ depth). The soil organic matter was $10.2 \%$ ( 0 to $15 \mathrm{~cm}$ depth). The soil contained $575 \mathrm{~g} \cdot \mathrm{kg}^{-1}$ sand, $84 \mathrm{~g} \cdot \mathrm{kg}^{-1}$ silt, and $341 \mathrm{~g} \cdot \mathrm{kg}^{-1}$ clay. The land was very stony and moderately rocky.

The $\mathrm{N}$ was applied in the form of ammonium sulfate, except in the first production cycle (2000-01) where urea was used, $\mathrm{P}$ in the form of triple super phosphate, and $\mathrm{K}$ in the form of potassium chloride. The fertilizers were applied at the onset of shoot emergence from rhizomes in early spring (first week of April) of the sprout year of the production. Fertilizer treatment combinations were applied using a Scott SR2000 rotary fertilizer spreader (Marysville, $\mathrm{OH}$ ). This site was continuously managed under commercial industry standards for Nova Scotia with provisions for pruning, agrochemical applications, and introduction of pollinators (honeybees) (Kaur et al., 2012).

Stem samples were collected in the month of July during 2001, 2003, 2005, 2007, 2009, and 2011 (crop year of production) using a 7.5 -m-long rope that was extended diagonally in each plot marked at 15 equally spaced points One stem was randomly collected at each mark.
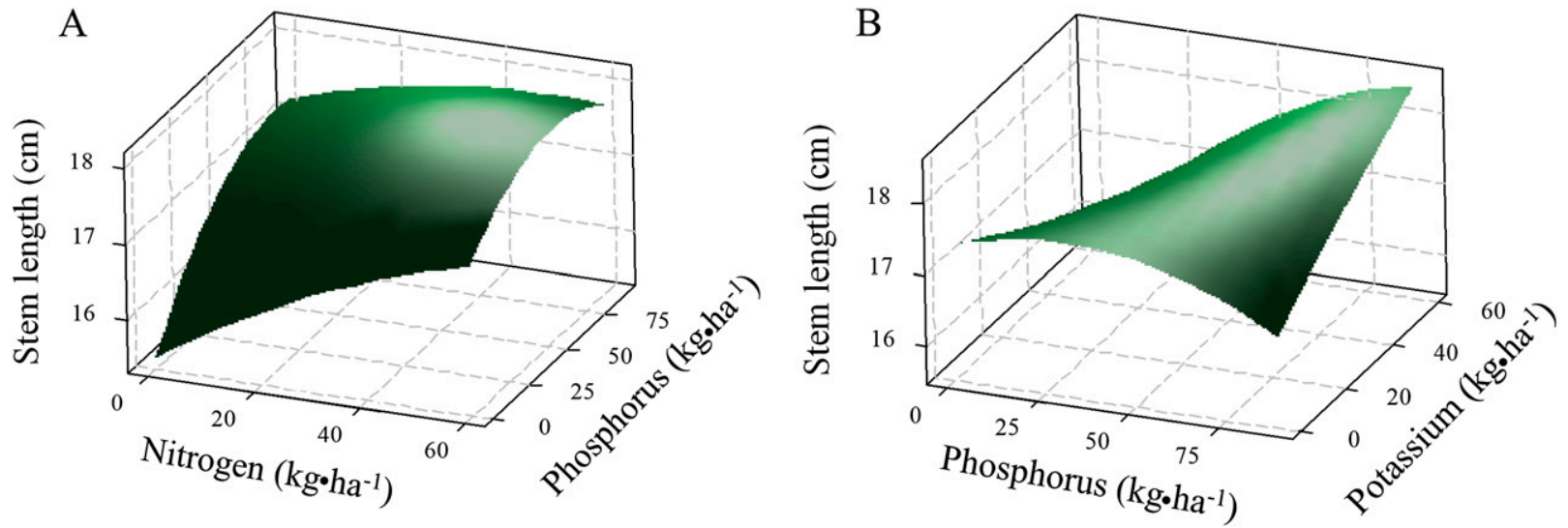

Fig. 1. Response surface of stem length $(\mathrm{cm})$ : $(\mathbf{A})$ the effect of nitrogen $\left(\mathrm{kg} \cdot \mathrm{ha}^{-1} \mathrm{~N}\right)$ and phosphorus $\left(\mathrm{kg} \cdot \mathrm{ha} \mathrm{a}^{-1} \mathrm{P}\right)$ for potassium fixed at $30 \mathrm{~kg} \cdot \mathrm{ha}{ }^{-1} \mathrm{~K}$ and $(\mathbf{B})$ the effect of phosphorus $\left(\mathrm{kg} \cdot \mathrm{ha}{ }^{-1} \mathrm{P}\right)$ and potassium $\left(\mathrm{kg} \cdot \mathrm{ha}^{-1} \mathrm{~K}\right)$ for nitrogen fixed at $30 \mathrm{~kg} \cdot \mathrm{ha} \mathrm{H}^{-1} \mathrm{~N}$. 
Table 3. Canonical analysis performed for each response surface model.

\begin{tabular}{|c|c|c|c|c|c|}
\hline \multirow[b]{2}{*}{ Responses (units) } & \multicolumn{3}{|c|}{ Stationary points in real units $\left(\mathrm{kg} \cdot \mathrm{ha}^{-1}\right)$} & \multirow[b]{2}{*}{$\mathrm{Y}_{\mathrm{S}}$} & \multirow{2}{*}{$\begin{array}{c}\text { Nature of } \\
\text { stationary point }\end{array}$} \\
\hline & $\mathrm{N}$ & $\mathrm{P}$ & $\mathrm{K}$ & & \\
\hline Stem length (cm) & 50 & 48 & 30 & 17.8 & Saddle \\
\hline $\begin{array}{l}\text { Vegetative nodes } \\
\text { (nodes per stem) }\end{array}$ & 49 & 48 & 65 & 16.9 & Maximum \\
\hline Floral nodes (nodes per stem) & 34 & 45 & 30 & 5.7 & Maximum \\
\hline Berries per stem & 40 & 38 & 33 & 11.9 & Saddle \\
\hline Berry yield $\left(\mathrm{kg} \cdot \mathrm{ha}^{-1}\right)$ & 30 & 45 & 32 & 4126 & Saddle \\
\hline
\end{tabular}

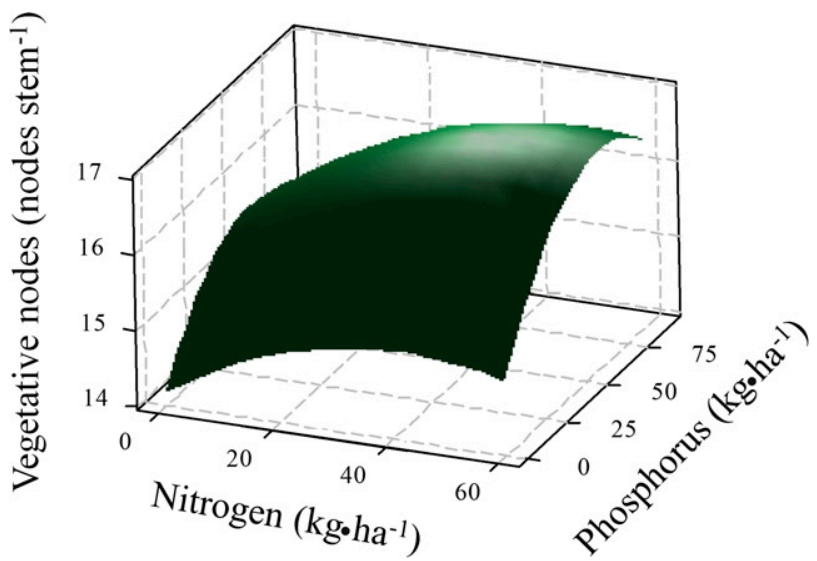

Fig. 2. Response surface of vegetative nodes (nodes per stem): the effect of nitrogen $\left(\mathrm{kg} \cdot \mathrm{ha} \mathrm{C}^{-1} \mathrm{~N}\right)$ and phosphorus $\left(\mathrm{kg} \cdot \mathrm{ha}^{-1} \mathrm{P}\right)$ for potassium fixed at $30 \mathrm{~kg} \cdot \mathrm{ha}^{-1} \mathrm{~K}$.

Stem samples were stored in plastic bags in a cooler and transported to the laboratory. Stem length $(\mathrm{cm})$ was measured from ground level to the apical bud. In case of branching, the longest distance was recorded. Vegetative nodes, floral nodes, and berries per stem were counted both on main stems, including those of any branches. Stem length, vegetative nodes, and floral nodes were determined for each collected stem (15 stems per plot) and averaged to get a single value for each plot. Harvests occurred on a single day in mid to end of August in crop year of production. Berries were harvested with a 40-tine commercial wild blueberry hand-rake (Acadian Machine Works Ltd., Tignish, PEI) from four randomly selected $1-\mathrm{m}^{2}$ quadrants in each plot (Kinsman, 1993; Percival and Sanderson, 2004). Harvested berry yield was recorded using a digital balance (Mettler PE 6000, Burlington, $\mathrm{ON}$ ).

Statistical analysis. To improve the precision of parameter estimations, the averages of the four replications were used, except the center point, which the CCD calls for the replications to allow lack of fit tests (Myers et al., 2009). The data from all years were analyzed together using year as a blocking factor to account for year-to-year variability. Minitab 16 software (Minitab Inc., State College, PA) was used for response surface analyses of the data. The lack of fit test measures the adequacy of the quadratic response surface model. We tested models for lack of fit test to make sure there is no lack of second order model and proceeded to surface plots and canonical analysis to pin point the optimum settings (Myers et al., 2009). Threedimensional (3D) surface plots were drawn to illustrate the interactive effects of the factors on the response variables. The optimum settings of the factors were obtained by completing canonical analysis (Myers et al., 2009). Matlab 7.10 (The Mathworks, Inc., Natick, MA) was used to complete canonical analysis of the data.

\section{Results and Discussion}

The analysis of variance $P$ values for all responses are provided in Table 2. For all responses, the lack of fit test results was not significant, suggesting that the quadratic model adequately fit for all responses and the design settings are in the neighborhood of the optimum setting. The regression models for stem length, vegetative and floral nodes, berries per stem, and berry yield were all significant at the $5 \%$ level of significance (Table 2 ).

Stem length. The optimal value of $17.8 \mathrm{~cm}$ for stem length was obtained with fertilizer rates of $50 \mathrm{~kg} \cdot \mathrm{ha}^{-1} \mathrm{~N}, 48 \mathrm{~kg} \cdot \mathrm{ha}^{-1} \mathrm{P}$, and $30 \mathrm{~kg} \cdot \mathrm{ha}^{-1} \mathrm{~K}$ (Fig. 1; Table 3). The goal was to find a fertilizer dose that maintained a stem length of $<20 \mathrm{~cm}$ without negatively affecting yield potentials. The stem length $(17.8 \mathrm{~cm})$ is not excessive considering high rate of $\mathrm{N}$ used $\left(50 \mathrm{~kg} \cdot \mathrm{ha}^{-1}\right)$. This may be the effect (regulation of $\mathrm{N}$ uptake and/or timely transition to reproductive phase) of complete $\mathrm{N}-\mathrm{P}-\mathrm{K}$ fertilization or genetic potential of the clones at our experimental site. $\mathrm{P}$ has been known to counteract the adverse effects (excessive vegetative growth) of excess $\mathrm{N}$. The fertilizer $\mathrm{N}$ rate that correlated best for stem length in this study was higher than those typically observed in the highly productive fields of Nova Scotia under favorable conditions (unpublished data).
The soil-applied N (0-60 kg.ha $\left.{ }^{-1}\right)$ and $\mathrm{P}$ $\left(0-50 \mathrm{~kg} \cdot \mathrm{ha}^{-1}\right)$ significantly increased stem length (Fig. 1A). However, higher $\mathrm{P}$ rates $\left(>65 \mathrm{~kg} \cdot \mathrm{ha}^{-1}\right.$ ) reduced stem length (Fig. 1B). The $\mathrm{P} \times \mathrm{K}$ interaction was significant (Table 2 ) as depicted by the saddle nature of the $3 \mathrm{D}$ surface plot (Fig. 1B). Increased stem length by fertilization ( $\mathrm{N}$ or NP) has been consistently reported in earlier studies (Percival and Sanderson, 2004; Smagula and Dunham, 1995) but interestingly, stems never exceeded $20 \mathrm{~cm}$ in this study. The floral buds on the excessively tall stems may be damaged by winter injury. The injury occurs in case of inadequate snow cover during the winter. Furthermore, the taller stems may lodge in the crop year of production combined with hindering of the mechanical harvest, and may adversely affect final berry yield (visual observation).

Vegetative nodes. Vegetative node number increased as a function of increased $\mathrm{N}$ and $P$ rates but was unaffected by $K$ fertilizer (Table 2; Fig. 2). The increase in vegetative nodes in response to fertilization is consistent with earlier studies (Jeliazkova and Percival, 2003). The goal was to maximize the reproductive output while limiting the excessive vegetative growth. The maximum number of vegetative nodes per stem occurred at fertilizer rates of $49 \mathrm{~kg} \cdot \mathrm{ha}^{-1} \mathrm{~N}, 48 \mathrm{~kg} \cdot \mathrm{ha}^{-1} \mathrm{P}$, and $65 \mathrm{~kg} \cdot \mathrm{ha}^{-1} \mathrm{~K}$ (Table 3 ). The fertilizer $\mathrm{N}-\mathrm{P}-\mathrm{K}$ rates for maximum vegetative nodes were higher than required to maximize yield components (floral nodes, berries per stem) with $\mathrm{K}$ even exceeding the experimental range. This serves the final goal of limiting the vegetative growth while simultaneously maximizing the reproductive output. The high $\mathrm{N}$ rates gave the greatest stem length $\left(50 \mathrm{~kg} \cdot \mathrm{ha}^{-1}\right)$ and vegetative nodes $\left(49 \mathrm{~kg} \cdot \mathrm{ha}^{-1}\right)$ but $\mathrm{N}$ rates $\left(30-40 \mathrm{~kg} \cdot \mathrm{ha}^{-1}\right)$ at a much lower levels provided the optimal response in reproductive variables (Table 3).

Floral nodes. Floral nodes had significant convex quadratic response to $\mathrm{N}-\mathrm{P}-\mathrm{K}$ fertilizer (Table 2; Fig. 3). The maximum number of floral nodes per stem were found with fertilizer rates of $34 \mathrm{~kg} \cdot \mathrm{ha}^{-1} \mathrm{~N}, 45 \mathrm{~kg} \cdot \mathrm{ha}^{-1} \mathrm{P}$, and $30 \mathrm{~kg} \cdot \mathrm{ha}^{-1} \mathrm{~K}$. The 3.7 nodes per stem that was obtained at current fertilizer recommendations increased to 5.7 nodes per stem at our optimum levels, an increase of 54\% (Table 3 ). The response surface plots also depicted $\approx 5.7$ nodes per stem at our fertilizer combinations (Fig. 3). Other studies demonstrated that N-P fertilizer increased floral nodes (Smagula and Dunham, 1995; Smagula et al., 2004). Our results confirm that high levels of soil P may retard the formation of reproductive organs (Marschner, 1995), whereas inadequate levels can delay flower initiation (Rossiter, 1978) and decrease the number of flowers (Bould and Parfitt, 1973).

Berries per stem. Berries per stem increased as the $\mathrm{N}$ rate increased from 0 to $40 \mathrm{~kg} \cdot \mathrm{ha}^{-1}$ regardless of $\mathrm{P}$ and $\mathrm{K}$ (Table 2; Fig. 4A). A significant negative $\mathrm{P} \times \mathrm{K}$ interaction was found for berries per stem (Table 2; Fig. 4B). At low $\mathrm{P}$ rates $\left(0-20 \mathrm{~kg} \cdot \mathrm{ha}^{-1}\right)$ berries per stem increased when $\mathrm{K}$ was increased linearly (Fig. 4B). However at high P levels $\left(>60 \mathrm{~kg} \cdot \mathrm{ha}^{-1}\right)$, 

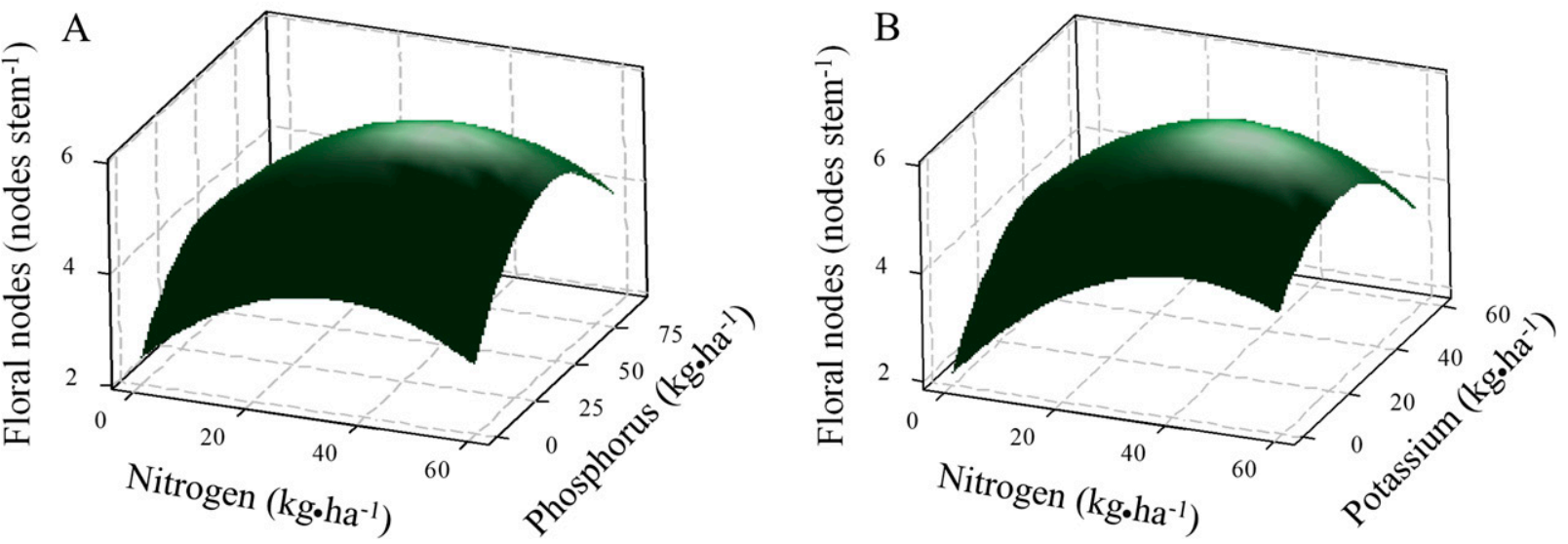

Fig. 3. Response surface of floral nodes (nodes per stem): (A) the effect of nitrogen $\left(\mathrm{kg} \cdot \mathrm{ha} \mathrm{a}^{-1} \mathrm{~N}\right)$ and phosphorus $\left(\mathrm{kg} \cdot \mathrm{ha} \mathrm{a}^{-1} \mathrm{P}\right)$ for potassium fixed at $30 \mathrm{~kg} \cdot \mathrm{ha} \mathrm{C}^{-1} \mathrm{~K}$ and (B) the effect of nitrogen $\left(\mathrm{kg} \cdot \mathrm{ha}^{-1} \mathrm{~N}\right)$ and potassium $\left(\mathrm{kg} \cdot \mathrm{ha}^{-1} \mathrm{~K}\right)$ for phosphorous fixed at $45 \mathrm{~kg} \cdot \mathrm{ha}^{-1} \mathrm{P}$
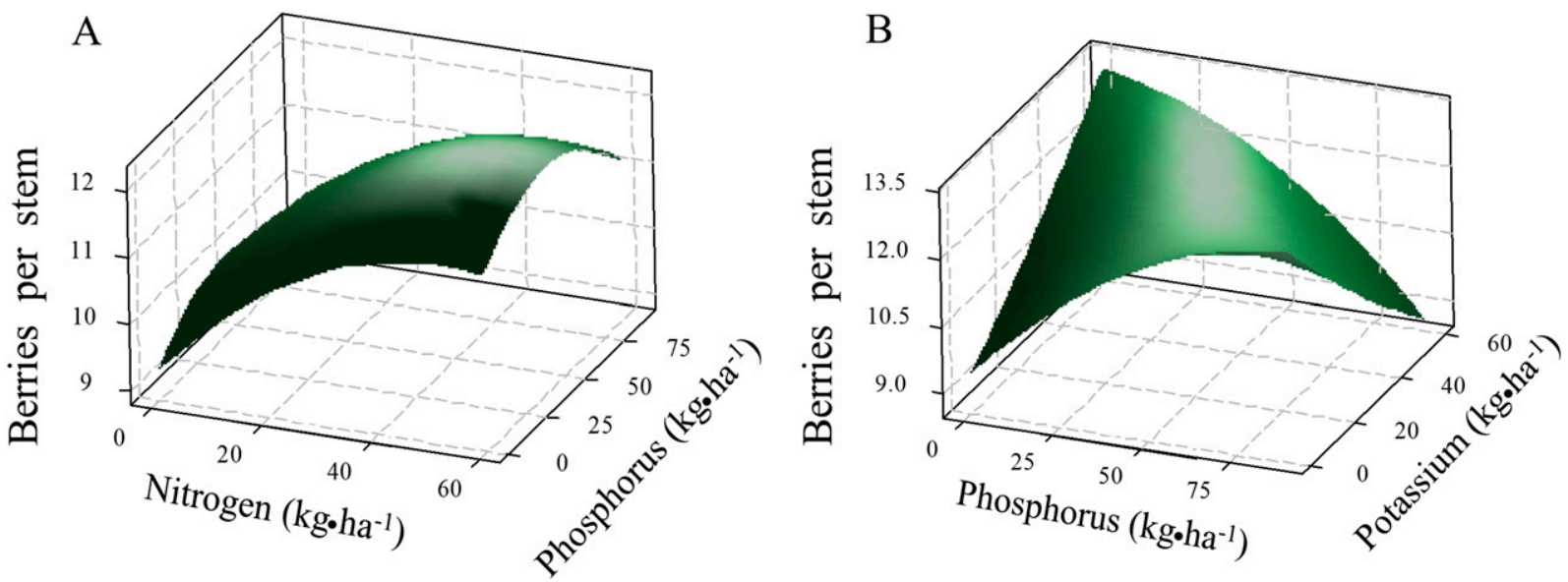

Fig. 4. Response surface of berries per stem: $(\mathbf{A})$ the effect of nitrogen $\left(\mathrm{kg} \cdot \mathrm{ha}^{-1} \mathrm{~N}\right)$ and phosphorus $\left(\mathrm{kg} \cdot \mathrm{ha} \mathrm{h}^{-1} \mathrm{P}\right)$ for potassium fixed at $30 \mathrm{~kg} \cdot \mathrm{ha} \mathrm{a}^{-1} \mathrm{~K}$ and $(\mathbf{B})$ the effect of phosphorus $\left(\mathrm{kg} \cdot \mathrm{ha}^{-1} \mathrm{P}\right)$ and potassium $\left(\mathrm{kg} \cdot \mathrm{ha}^{-1} \mathrm{~K}\right)$ for nitrogen fixed at $30 \mathrm{~kg} \cdot \mathrm{ha}^{-1} \mathrm{~N}$.

berries per stem decreased with increasing $\mathrm{K}$ fertilization (Fig. 4B). The optimal berries per stem (11.9) was obtained at $\mathrm{N}, \mathrm{P}$, and $\mathrm{K}$ rates of 40,38 , and $33 \mathrm{~kg} \cdot \mathrm{ha}^{-1}$, respectively. Berries per stem were $25 \%$ greater with these optimal levels as compared with the current fertilizer recommendations. Glass et al. (2005) reported the most significant correlation $(R=0.82)$ between floral nodes and berries per stem. This relationship is evident from floral nodes and berries per stem plots (Figs. 3A and 4A) where optimal fertilizer rates were very similar for these two yield components.

Berry yield. The rates of N-P-K fertilizer calculated for optimal berry yield were $30 \mathrm{~kg} \cdot \mathrm{ha}^{-1}, 45 \mathrm{~kg} \cdot \mathrm{ha}^{-1}$, and $32 \mathrm{~kg} \cdot \mathrm{ha}^{-1}$, respectively (Table 3 ). The berry yield at optimum fertilizer levels was $4126 \mathrm{~kg} \cdot \mathrm{ha}^{-1}$, which is $14 \%$ higher compared with the commonly used industry standard and 23\% higher compared with Nova Scotia's average production $\left(3350 \mathrm{~kg} \cdot \mathrm{ha}^{-1}\right)$ for the years harvested in this study. The optimal N-P-K fertilizer produced $520 \mathrm{~kg} \cdot \mathrm{ha}^{-1}$ more berry yield and increased the costs by $\$ 80 /$ ha relative to the industry standard $\mathrm{N}-\mathrm{P}-\mathrm{K}$ rates. The increase in berry yield gave additional farm gate value of $\$ 575 / \mathrm{ha}(\$ 0.5 / \mathrm{lb})$ and a net profit of $\$ 490 / \mathrm{ha}$. This optimal yield is greater than values reported from commercial fields in Nova Scotia over the past 12 years (unpublished data).

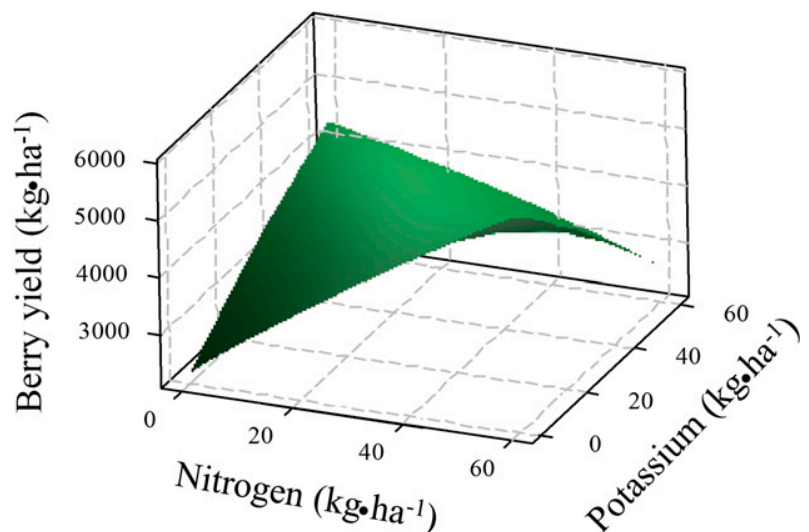

Fig. 5. Response surface of berry yield $\left(\mathrm{kg} \cdot \mathrm{ha}^{-1}\right)$ : the effect of nitrogen $\left(\mathrm{kg}^{\mathrm{h}} \mathrm{ha}^{-1} \mathrm{~N}\right)$ and potassium $\left(\mathrm{kg} \cdot \mathrm{ha} \mathrm{a}^{-1}\right.$ $\mathrm{K})$ for phosphorus fixed at $45 \mathrm{~kg} \cdot \mathrm{ha}^{-1} \mathrm{P}$.

However, the increase in berry yield is not as high as those found for floral nodes $(54 \%)$ and berries per stem $(25 \%)$. The smaller increase in berry yield may be attributed to uncontrollable factors such as climate (temperature, precipitation, wind, etc.), inadequate bee population and pollination (Eaton and Nams, 2012), disease pressures, or controllable factors such as poor harvesting techniques (Kinsman, 1993).

$\mathrm{N}$ was the most important fertilizer increasing berry yield (Fig. 5) agreeing with previous reports (Percival and Sanderson, 2004).
A significant negative $\mathrm{N} \times \mathrm{K}$ interaction is depicted by $3 \mathrm{D}$ surface plots (Fig. 5) where at low $\mathrm{N}$ rates $\left(0-20 \mathrm{~kg} \cdot \mathrm{ha}^{-1}\right)$ berry yield increased linearly with $\mathrm{K}\left(0-60 \mathrm{~kg} \cdot \mathrm{ha}^{-1}\right)$, whereas it decreased with medium-to-high $\mathrm{N}$ rates $(>30$ $\mathrm{kg} \cdot \mathrm{ha}^{-1}$; Fig. 5). The negative $\mathrm{N} \times \mathrm{K}$ interaction may be explained by soil ammonium $\left(\mathrm{NH}_{4}{ }^{+}\right)$ and $\mathrm{K}^{+}$competition for exchange sites. $\mathrm{NH}_{4}{ }^{+}$ and $\mathrm{K}^{+}$have the same affinity for exchange sites and also can remove each other from soil colloid surfaces when high concentrations are present, such as when fertilizers are applied 
(Pugh, 2008). The high rate of $\mathrm{K}$ fertilizer $(>40$ $\mathrm{kg} \cdot \mathrm{ha}^{-1}$ ) may have increased concentration of $\mathrm{K}^{+}$ions in the soil solution and displaced $\mathrm{NH}_{4}{ }^{+}$ ions from exchange sites. The increased $\mathrm{NH}_{4}{ }^{+}$ availability at high $\mathrm{K}$ fertilizer rates $(>40$ $\mathrm{kg} \cdot \mathrm{ha}^{-1}$ ) in soil solution and subsequent increased plant uptake, may have induced imbalance in the plant nutrients ( $\mathrm{N}$ and $\mathrm{K}$ ). This imbalance may have delayed the transition from vegetative to reproductive phase in the plant. A prolonged vegetative phase (late transition to reproductive phase) may cause a reduction in the development of floral buds and the resulting berry yield. However, application of $\mathrm{K}$ may be necessary to avoid a flush of growth when $\mathrm{N}$ is applied without $\mathrm{K}$. It may prevent lodging and guard plant against fungal pathogens.

Considering the significant quadratic (convex) effect of soil-applied $\mathrm{P}$ on floral nodes and positive $\mathrm{P}$ and $\mathrm{K}$ interaction effect on berries per stem (Table 2; Figs. 3A and 4B), the nonsignificant $P$ effect on berry yield was somewhat surprising. Previous studies have reported significantly enhanced yield of wild blueberry from increased P (Litten et al., 1997; Smagula and Dunham, 1995), whereas others reported no effect (Sanderson and Eaton, 2008). Percival and Sanderson (2004) noted a reduction in stem density to soilapplied $\mathrm{P}$ and this may explain the lack of linear significant yield increase. In addition, $\mathrm{N}$ has been reported to be an active diluter of $\mathrm{P}$ in wild blueberries since continued use of $\mathrm{N}$ applications may decrease leaf $\mathrm{P}$ content and induce an imbalance and/ or deficiency (Trevett et al., 1968). P application may be critical to keep foliar P levels in optimal range required for optimal reproductive organ growth without direct berry yield gains. This study reported the effect of N-P-K in the sprout year of production. Further potential increases in harvestable yield may be tested in future studies by splitting fertilizer doses between sprouting and cropping years. Percival et al. (2003) exhibited that multiple fertilizer applications can improve the nutrient status, growth, and harvestable yield of wild blueberries. Multiple fertilizer applications (initial fertilizer dose of $28 \mathrm{~kg} \cdot \mathrm{ha}^{-1} \mathrm{~N}, 12 \mathrm{~kg} \cdot \mathrm{ha}^{-1}$ $\mathrm{P}$, and $23 \mathrm{~kg} \cdot \mathrm{ha}^{-1} \mathrm{~K}$ in the sprout year +10 $\mathrm{kg} \cdot \mathrm{ha}^{-1} \mathrm{~N}$ was added before bloom of the crop year) increased berry yield by $51 \%$ over single application of initial fertilizer dose of $28 \mathrm{~kg} \cdot \mathrm{ha}^{-1}$ $\mathrm{N}, 12 \mathrm{~kg} \cdot \mathrm{ha}^{-1} \mathrm{P}$, and $23 \mathrm{~kg} \cdot \mathrm{ha}^{-1} \mathrm{~K}$ in the sprout year.

Simultaneous optimization of stem length, floral nodes, berries per stem, and berry yield. The fertilizer rates for optimal stem length, floral nodes, berries per stem, and berry yield were obtained by overlaying the plots and looking at the "sweet spots" (Myers et al., 2009). The primary objective of this study was to maximize reproductive output while avoiding excessive vegetative growth. This was achieved by maximizing the floral nodes, berries per stem, and berry yield while maintaining stem length below $20 \mathrm{~cm}$. This contour plot overlaid the response surface models for our four variables (stem length, floral nodes, berries per stem, and berry yield)

A

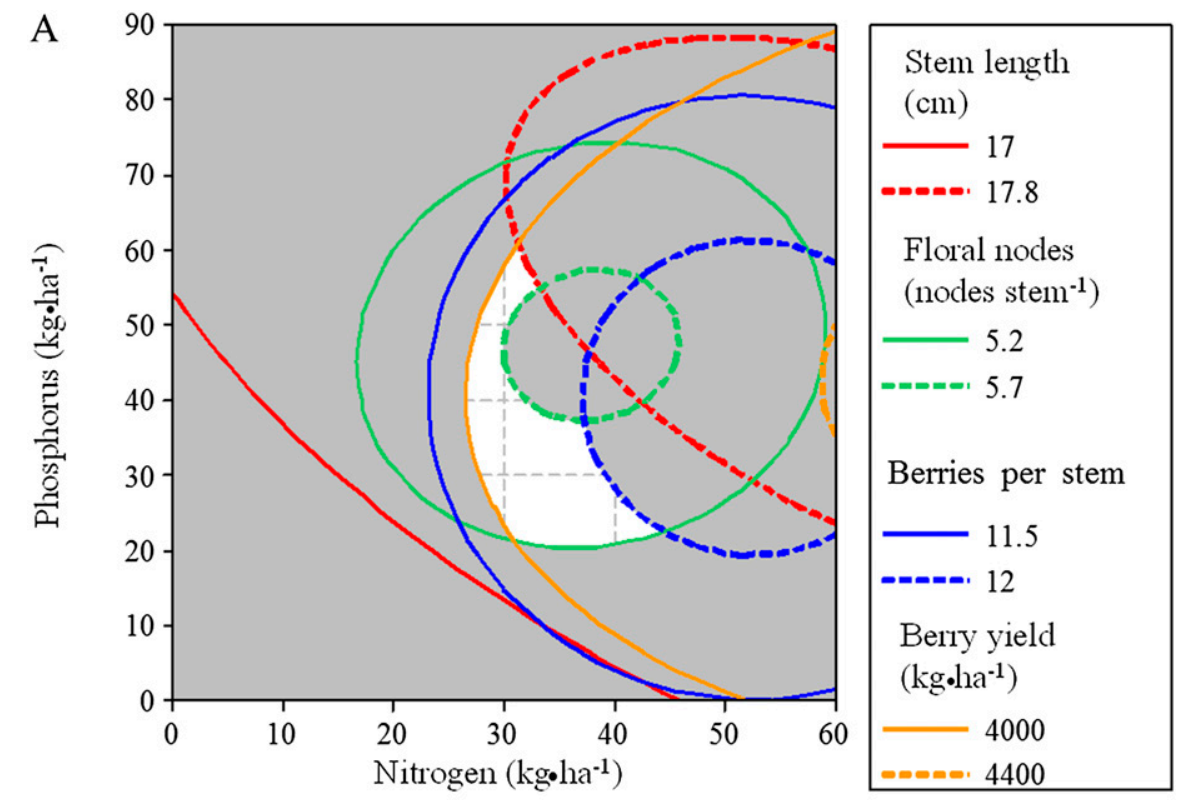

Stem length

(cm)

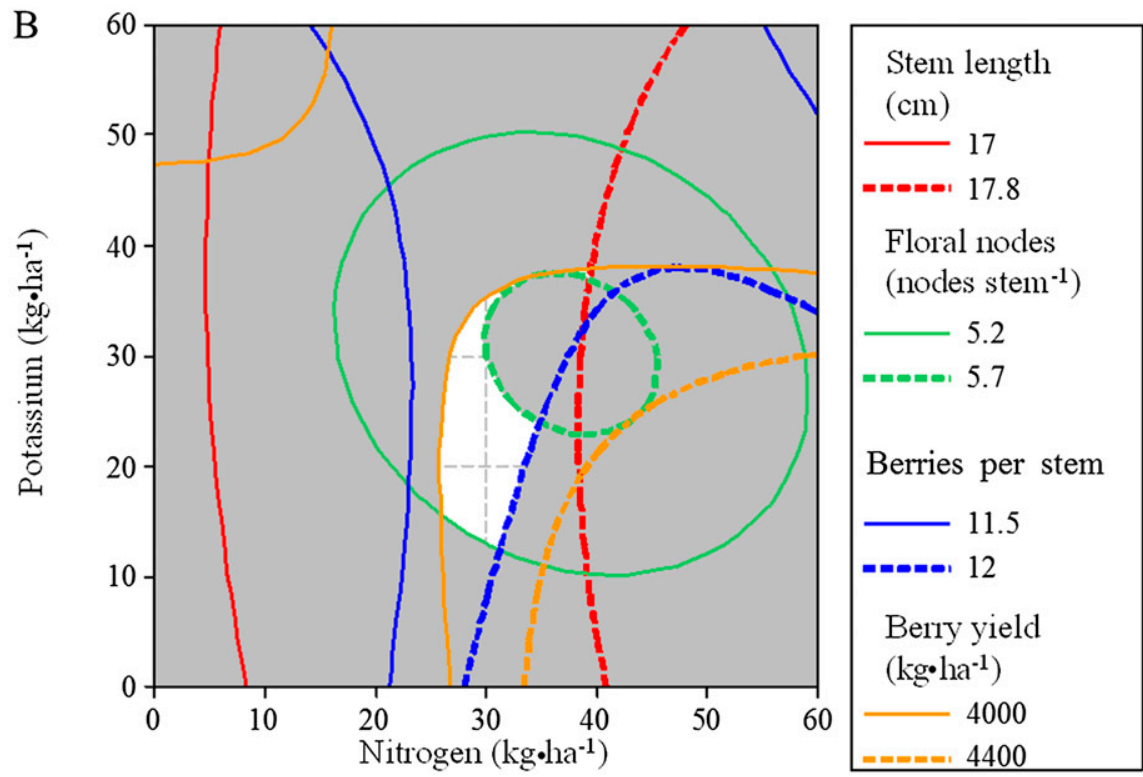

Fig. 6. Overlaid contour plot of four response surface models: (A) the effect of nitrogen $\left(\mathrm{kg} \cdot \mathrm{ha}^{-1} \mathrm{~N}\right)$ and phosphorus $\left(\mathrm{kg} \cdot \mathrm{ha}^{-1} \mathrm{P}\right)$ for potassium fixed at $30 \mathrm{~kg} \cdot \mathrm{ha}^{-1} \mathrm{~K}$ on stem length, floral nodes, berries per stem, and berry yield and $(\mathbf{B})$ the effect of nitrogen $\left(\mathrm{kg} \cdot \mathrm{ha}^{-1} \mathrm{~N}\right)$ and potassium $\left(\mathrm{kg} \cdot \mathrm{ha}^{-1} \mathrm{~K}\right)$ for phosphorus fixed at $45 \mathrm{~kg} \cdot \mathrm{ha}^{-1} \mathrm{P}$ on stem length, floral nodes, berries per stem, and berry yield. The white area is the "sweet spot" where the criteria of all four responses are fulfilled.

overall the ranges of applied fertilizers (Fig. 6). The sweet spot (white area) is the area where all responses are optimized (Fig. 6). The optimal range obtained from the overlay plot was found to be between $30-40 \mathrm{~kg} \cdot \mathrm{ha}^{-1} \mathrm{~N}, 25-60 \mathrm{~kg} \cdot \mathrm{ha}^{-1}$ $\mathrm{P}$, and $20-30 \mathrm{~kg} \cdot \mathrm{ha}^{-1} \mathrm{~K}$. The graphically derived values (sweet spot) matched closely to the numerically derived value through canonical analysis (Table 3).

\section{Conclusions}

Based on the results of the study, we recommend applying $35 \mathrm{~kg} \cdot \mathrm{ha}^{-1} \mathrm{~N}, 40 \mathrm{~kg} \cdot \mathrm{ha}^{-1}$ $\mathrm{P}$, and $30 \mathrm{~kg} \cdot \mathrm{ha}^{-1} \mathrm{~K}$ at the onset of shoot emergence each sprout year in lowbush blueberry in central Nova Scotia. These rates optimized floral bud number, berries per stem, and berry yield, without resulting in excessive stem growth (stem lengths $>20 \mathrm{~cm}$ are considered too long and result in reduced harvest efficiency), and should be tested in other lowbush growing regions such as Maine, New Brunswick, Ontario, and Quebec.

\section{Literature Cited}

Agriculture Canada. 1991. Soils of Colchester County, Nova Scotia. Nova Scotia Soil Survey. Report No. 16:64-65.

Benoit, G.R., W.J. Grant, A.A. Ismail, and D.E. Yarborough. 1984. Effect of soil moisture and fertilizer on the potential and actual yield of lowbush blueberries. Can. J. Plant Sci. 64: 683-689. 
Blatt, C.R. 1993. Effect of nitrogen, phosphorus and potassium additions in field and glasshouse experiments on soil and leaf nutrient values, vegetative growth and marketable crop yield of lowbush blueberries. J. Small Fruit Viticult. 1 (4):29-35

Bould, C. and R.I. Parfitt. 1973. Leaf analysis as a guide to the nutrition of fruit crops. X. Magnesium and phosphorus sand culture experiments with apple. J. Sci. Food Agr. 24:175-185.

Cain, J.C. 1952. A comparison of ammonium and nitrate nitrogen for blueberries. Proc. Amer. Soc. Hort. Sci. 59:161-166.

Eaton, L.J. and V.O. Nams. 2012. Honey bee stocking numbers and wild blueberry production in Nova Scotia. Can. J. Plant Sci. 92:1305-1310.

Eaton, L.J., G.W. Stratton, and K.R. Sanderson. 1997. Fertilizer phosphorus in lowbush blueberries: Effects and fate. Acta Hort. 446:477-486.

Eck, P. 1983. Optimum potassium nutritional level for production of highbush blueberry. J. Amer. Soc. Hort. Sci. 108:520-522.

Glass, V.M., D.C. Percival, and J.T.A. Proctor. 2005. Tolerance of lowbush blueberries ( $\mathrm{Vac}$ cinium angustifolium Ait.) to drought stress. I. Soil water and yield component analysis. Can. J. Plant Sci. 85:911-917.

Ismail, A.A., J.M. Smagula, and D.E. Yarborough. 1981. Influence of pruning method, fertilizer, and terbacil on the growth and yield of the lowbush blueberry. Can. J. Plant Sci. 61:61-71.

Jeliazkova, E.A. and D.C. Percival. 2003. N and P fertilizers, some growth variables, and mycorrhizae in wild blueberry (Vaccinium angustifolium). Acta Hort. 626:297-304.

Kaur, J., D. Percival, L.J. Hainstock, and J.P. Privé. 2012. Seasonal growth dynamics and carbon allocation of the wild blueberry plant ( $\mathrm{Vac}$ cinium angustifolium Ait.). Can. J. Plant Sci. 92:1145-1154.

Kinsman, G. 1993. The history of the lowbush blueberry industry in Nova Scotia 1950-1990. The Blueberry Producer's Assoc. of Nova Scotia.

Lippke, H., V.A. Vincent, and T.L. Provin. 2006. Irrigated annual ryegrass responses to nitrogen and phosphorus on calcareous soil. Agron. J. 98:1333-1339.
Litten, W., J.M. Smagula, and S. Dunham. 1997. Blueberry surprise from phosphorous. Maine Agr. Forest Expt. Sta. RPT. 404. Univ. Maine, Orono, ME.

Maqbool, R. 2014. Nitrogen cycling, optimization of plant nutrition and remote sensing of leaf nutrients in wild blueberries (Vaccinium angustifolium Ait.) in wild blueberry. $\mathrm{PhD}$ Thesis. Dalhousie University, Halifax, NS.

Marschner, H. 1995. Mineral nutrition of higher plants. 2nd ed. Academic Press Ltd., London.

Myers, R.H., D.C. Montgomery, and C.M. AndersonCook. 2009. Response surface methodology process and product optimization using designed experiments. 3rd ed. Wiley, New York, NY.

Näsholm, T., A. Ekblad, A. Nordin, R. Giesler, M. Högberg, and P. Högberg. 1998. Boreal forest plants take up organic nitrogen. Nature 392 227-229.

Penney, B.G. and K.B. McRae. 2000. Herbicidal weed control and crop-year NPK fertilization improves lowbush blueberry (Vaccinium angustifolium Ait.) production. Can. J. Plant Sci. 80: 351-361.

Percival, D.C. and K.R. Sanderson. 2004. Main and interactive effects of vegetative-year applications of nitrogen, phosphorus and potassium fertilizers on the wild blueberry. Small Fruits Rev. 3:105-121.

Percival, D.C., D.E. Janes, D.E. Stevens, and K. Sanderson. 2003. Impact of multiple fertilizer applications on plant growth, development, and yield of wild lowbush blueberry (Vaccinium angustifolium Aiton). Acta Hort. 626:415-421.

Persson, J. and T. Näsholm. 2001. Amino acid uptake: A widespread ability among boreal forest plants. Ecol. Lett. 4:434 438 .

Pugh, B.C. 2008. Characterization of soil potassium pools and rice potassium uptake by rice grown on a potassium sufficient Dewitt silt loam during the growing season, p. 2-30. Masters Thesis, University of Arkansas, Fayetteville, AR.

Read, D.J., J.R. Leake, and J. Perez-Moreno. 2004. Mycorrhizal fungi as drivers of ecosystem processes in heathland and boreal forests biomes. Can. J. Bot. 82:1243-1263.
Rossiter, R.C. 1978. Phosphorus deficiency and flowering in subterranean clover (Tr. Subterraneum L.). Ann. Bot. (Lond.) 42:325-329.

Sanchez, C.A. 2000. Response of lettuce to water and nitrogen on sand and the potential for leaching of nitrate-N. HortScience 35:73-77.

Sanderson, K.R. and L.J. Eaton. 2008. Wild blueberry response to phosphorus applied to Prince Edward Island soils. Can. J. Plant Sci. 88: 363-366.

Smagula, J.M. 1999. Lowbush blueberry nutrition series: N-P-K. Wild Blueberry Fact sheet No. 223. Univ. Maine Coop. Ext. Orono, ME.

Smagula, J.M. and A.A. Ismail. 1981. Effect of fertilizer application, preceded by terbacil, on growth, leaf nutrient concentration, and yield of the lowbush blueberry Vaccinium angustifolium Ait. Can. J. Plant Sci. 61:961-964.

Smagula, J.M. and P.R. Hepler. 1978. Comparison of urea and sulfur-coated urea as nitrogen source for lowbush blueberries growing on a colton gravelly sandy loam. J. Amer. Soc. Hort. Sci. 103:818-820.

Smagula, J.M. and S. Dunham. 1995. Diammonium phosphate corrects phosphorus deficiency in lowbush blueberry. J. Small Fruit Viticult. 3:183-191.

Smagula, J.M., W. Litten, and K. Loennecker. 2004. Diammonium phosphate application date affects Vaccinium angustifolium Ait. nutrient uptake and yield. Small Fruits Rev. 3:87-94.

Townsend, L.R. 1969. Influence of form of nitrogen and $\mathrm{pH}$ on growth and nutrient levels in the leaves and roots of the lowbush blueberry. Can. J. Plant Sci. 49:333-338.

Townsend, L.R., I.V. Hall, and L.E. Aalders. 1968. Chemical composition of rhizomes and associated leaves of the lowbush blueberry. Proc. Amer. Soc. Hort. Sci. 93:248-253.

Trevett, M.F., P.N. Carpenter, and R.E. Durgin. 1968. A discussion of the effects of mineral nutrient interactions on foliar diagnosis in lowbush blueberries. Maine Agr. Exp. Sta. Bul. 664.

Yarborough, D.E., J.J. Hanchar, S.P. Skinner, and A.A. Ismail. 1986. Weed response, yield, and economics of hexazinone and nitrogen use in lowbush blueberry production. Weed Sci. 34:723-729. 